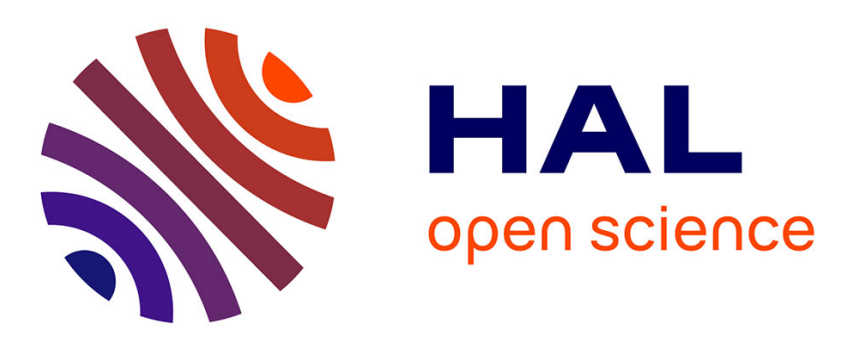

\title{
Involvement of PGC-1, NRF-1, and NRF-2 in metabolic response by rat liver to hormonal and environmental signals
}

\author{
P. Venditti, A. Bari, L. Di Stefano, A. Cardone, F. Della Ragione, M. \\ d'Esposito, S. Di Meo
}

\section{To cite this version:}

P. Venditti, A. Bari, L. Di Stefano, A. Cardone, F. Della Ragione, et al.. Involvement of PGC-1, NRF1 , and NRF-2 in metabolic response by rat liver to hormonal and environmental signals. Molecular and Cellular Endocrinology, 2009, 305 (1-2), pp.22. 10.1016/j.mce.2009.02.009 . hal-00499118

\section{HAL Id: hal-00499118 https://hal.science/hal-00499118}

Submitted on 9 Jul 2010

HAL is a multi-disciplinary open access archive for the deposit and dissemination of scientific research documents, whether they are published or not. The documents may come from teaching and research institutions in France or abroad, or from public or private research centers.
L'archive ouverte pluridisciplinaire HAL, est destinée au dépôt et à la diffusion de documents scientifiques de niveau recherche, publiés ou non, émanant des établissements d'enseignement et de recherche français ou étrangers, des laboratoires publics ou privés. 


\section{Accepted Manuscript}

Title: Involvement of PGC-1, NRF-1, and NRF-2 in metabolic response by rat liver to hormonal and environmental signals

Authors: P. Venditti, A. Bari, L. Di Stefano, A. Cardone, F. Della Ragione, M. D’Esposito, S. Di Meo

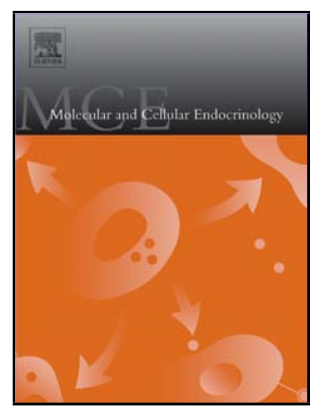

PII:

S0303-7207(09)00128-2

DOI: doi:10.1016/j.mce.2009.02.009

Reference: MCE 7142

To appear in: $\quad$ Molecular and Cellular Endocrinology

Received date: $\quad 31-10-2008$

Revised date: $\quad 28-1-2009$

Accepted date: $\quad$ 12-2-2009

Please cite this article as: Venditti, P., Bari, A., Di Stefano, L., Cardone, A., Ragione, F.D., D'Esposito, M., Di Meo, S., Involvement of PGC-1, NRF-1, and NRF-2 in metabolic response by rat liver to hormonal and environmental signals, Molecular and Cellular Endocrinology (2008), doi:10.1016/j.mce.2009.02.009

This is a PDF file of an unedited manuscript that has been accepted for publication. As a service to our customers we are providing this early version of the manuscript. The manuscript will undergo copyediting, typesetting, and review of the resulting proof before it is published in its final form. Please note that during the production process errors may be discovered which could affect the content, and all legal disclaimers that apply to the journal pertain. 


\title{
Involvement of PGC-1, NRF-1, and NRF-2 in metabolic response by rat liver to hormonal and environmental signals
}

\author{
P. Venditti*, A. Bari*, L. Di Stefano*, A. Cardone ${ }^{\dagger}$, F. Della Ragione \\ M. D'Esposito ${ }^{\#}$ and S. Di Meo* \\ * Dipartimento delle Scienze Biologiche, Sezione di Fisiologia, Università di Napoli, I-80134 \\ Napoli, Italy \\ ${ }^{\dagger}$ Dipartimento delle Scienze Biologiche, Sezione di Biologia Evolutiva e Comparata, Università di \\ Napoli, I-80134 Napoli, Italy \\ \# Institute of Genetics and Biophysics "A.Buzzati Traverso" - National Research Council (CNR) \\ Via P. Castellino 111, 80131, Naples, Italy
}

Address for correspondence to: Paola Venditti - Dipartimento delle Scienze Biologiche, Sezione di Fisiologia, Università di Napoli “Federico II”, Via Mezzocannone 8, I-80134, Napoli, Italy Telephone: (039)-(081)-2535080; Fax: (039)-(081)-2535090

E-Mailvenditti@unina.it 


\begin{abstract}
We studied liver oxidative capacity and $\mathrm{O}_{2}$ consumption in hypothyroid rats treated for 10 days with $\mathrm{T}_{4}$, or $\mathrm{T}_{3}$, or treated for 10 days with $\mathrm{T}_{3}$ and exposed to cold for the last two days. The metabolic response of homogenates and mitochondria indicated that all treatments increased the synthesis of respiratory chain components, whereas only the cold induced mitochondrial proliferation. Determination of mRNA and protein expression of transcription factor activators, such as NRF-1 and NRF-2, and coactivators, such as PGC-1, showed that mRNA levels, except PGC-1 ones, were not related to aerobic capacities. Conversely, a strong correlation was found was between cytochrome oxidase activity and PGC-1 or NRF-2 protein levels. Such a correlation was not found for NRF-1. Our results strongly support the view that in rat liver PGC-1 and NRFs are responsible for the iodothyronine-induced increases in respiratory chain components, whereas their role in cold-induced mitochondrial proliferation needs to be further on clarified.
\end{abstract}

Keywords: Cold-exposure, Thyroid hormone, Mitochondrial respiration, Mitochondrial proliferation, Transcription factor activators 


\section{Introduction}

Observations made in clinical and experimentally induced hyperthyroidism have shown that the main biological effect of thyroid hormone is to accelerate energy expenditure. In fact, the development of a hyperthyroid state in vertebrates leads to an increase in their metabolic rate due to an enhanced rate of $\mathrm{O}_{2}$ consumption in most of body tissues (Barker and Klitgaard, 1952). Although thyroxine $\left(\mathrm{T}_{4}\right)$ is the main product of thyroid secretion is widely shared the view that $T_{4}$ is only a prohormone and must be activated by deiodination to triiodothyronine $\left(T_{3}\right)$ in order to initiate thyroid hormone action. Thus, long-term effects of thyroid hormones or states modulating thyroid gland activity, such as cold exposure, are believed to be transduced through $\mathrm{T}_{3}$-induced changes in both nuclear and mitochondrial gene expression. In liver from both $\mathrm{T}_{3}$-treated (Fernández et al., 1985; Seitz et al., 1985; Venditti et al., 2006a) and cold-exposed animals (Guernsey and Stevens, 1977; Shiota et al., 1985; Venditti et al., 2004) such changes lead to enhanced tissue $\mathrm{O}_{2}$ consumption. However, in experimental hyperthyroidism the increase in liver respiration involves increases in the amount of respiratory chain proteins and inner surface area (Jacovcic et al., 1978) of mitochondria without changes in their number (Goglia et al., 1989) and protein mass (Venditti, et al., 2006a). Conversely, in cold-induced functional hyperthyroidism the increase in liver respiration involves proliferation of mitochondria (Goglia et al., 1983) associated with an enhancement in tissue content of mitochondrial proteins (Venditti et al., 2004; Venditti et al., 2006a).

The above results suggest that $T_{3}$ is responsible for the changes in hepatic content of respiratory chain components elicited by cold exposure and hormonal treatment. Conversely, other factors, exhibiting different serum concentrations in functional and experimental hyperthyroidism, should be involved in mitochondrial proliferation associated to cold exposure. Unlike cold exposure, $\mathrm{T}_{3}$ administration strongly decreases serum levels of $\mathrm{T}_{4}$, (Venditti et al., 2006a), which has been reported to have intrinsic biological activity in the cold (Cageao et al., 1992). Plasma levels of catecholamines, which are not modified in altered thyroid states (Stoffer et al., 1973), remarkably increase during cold exposure (Storm et al., 1981). Furthermore, a fall in liver mitochondria respiration is elicited by injection of adrenergic-receptor blockers to cold acclimated rats (Zaninovich et al., 2003).

In a previous work we used euthyroid rats to examine liver metabolic response to treatments, which differentially affect circulating $\mathrm{T}_{4}$ levels (Venditti et al., 2006a). Despite some supporting results, the idea 
that thyroxine can play a role in liver response to cold remains still to demonstrate. Therefore, in the present work we compared the effects on liver oxidative metabolism of 10 days of $T_{3}$ or $T_{4}$ treatment to rats made hyperthyroid by PTU and iopanoic acid to block the deiodinase activities (Obregon et al., 1980). To shown possible involvement of catecholamines in cold-induced metabolic changes, we also studied the effects of 2 day cold exposure $\left(4^{\circ} \mathrm{C}\right)$ on $\mathrm{T}_{3}$-treated hypothyroid rats. Moreover, metabolic responses were related to changes in the expression levels of nuclear respiratory factors-1 and -2 (NRF-1 and NRF-2) and nuclear receptor co-activator PGC-1, which are regulated by thyroid hormone (Weitzel et al., 2001) and play a role in the mitochondrial biogenesis (Scarpulla, 2002). 


\section{Materials and methods}

\subsection{Materials}

All chemicals used (Sigma Chimica, Milano, Italy) were of the highest grades available. Response to oxidative stress was determined by using reagents and instrumentation of the commercially available Amerlite System (Ortho-Clinical Diagnostics, Milano, Italy). Serum levels of free triiodothyronine ( $\left.\mathrm{FT}_{3}\right)$ and thyroxine $\left(\mathrm{FT}_{4}\right)$ were determined by using commercial RIA kits (DiaSorin, Salluggia, Italy).

\subsection{Animals}

The experiments were carried out on 70-day-old male Wistar rats, supplied by Nossan (Correzzana, Italy) at day 45 of age. From day 49, animals were randomly assigned to one of four groups: hypothyroid rats $(H)$, hypothyroid rats made hyperthyroid by $\mathrm{T}_{3}\left(\mathrm{HT}_{3}\right)$ or $\mathrm{T}_{4}\left(\mathrm{HT}_{4}\right)$ treatment, hypothyroid rats made hyperthyroid by $\mathrm{T}_{3}$ treatment and exposed for 2 days to cold $\left(\mathrm{HT}_{3}+\mathrm{CE}\right)$. In $\mathrm{H}$ rats, both thyroid and deiodinase activities were chronically inhibited by i.p. administration of PTU $(1 \mathrm{mg} / 100 \mathrm{~g}$ body weight, once per day for 3 weeks), together with administration of iopanoic acid (IOP) given to 10, 13, 16, 19, and 21 days after the first PTU injection. The other rats, which undergone the same treatment of $\mathrm{H}$ rats were also intraperitoneally administered with $\mathrm{T}_{4}\left(\mathrm{HT}_{4}\right)$ or with $\mathrm{T}_{3}\left(\mathrm{HT}_{3}\right.$ and $\left.\mathrm{HT}_{3}+\mathrm{CE}\right)(10 \mu \mathrm{g} / 100 \mathrm{~g}$ body weight, once per day for 10 days before sacrifice), and exposed to $4 \pm 1{ }^{\circ} \mathrm{C}$ for 2 days before sacrifice $\left(\mathrm{HT}_{3}+\mathrm{CE}\right) . \mathrm{H}, \mathrm{HT}_{3}$, and $\mathrm{HT}_{4}$ rats were kept at room temperature of $24 \pm 1^{\circ} \mathrm{C}$. The combined treatment with PTU and IOP inhibits both the production of thyroid hormones and all deiodinase enzymes. Thus, it excludes the possibility that the effects observed following the administration of iodothyronines can be attributed to any of their deiodinated products and cold exposure can change thyroid hormone levels. The rats were exposed to cold for two days because a such period is sufficient to induce remarkable mitochondrial proliferation (Venditti et al., 2004).

All rats were kept under the same environmental conditions and were provided with water ad libitum and commercial rat chow diet (Nossan).

The treatment of animals in these experiments was in accordance with the guidelines set forth by the University’s Animal Care Review Committee. 


\subsection{Tissue preparation}

The animals were sacrificed by decapitation while under ether anaesthesia. Arterial blood samples were collected and later analyzed to determine plasma levels of $\mathrm{FT}_{3}$ and $\mathrm{FT}_{4}$ by radioimmunoassay. Liver was rapidly excised and placed into ice-cold homogenization medium (HM) (220 mM mannitol, $70 \mathrm{mM}$ sucrose, $1 \mathrm{mM}$ EDTA, $0.1 \%$ fatty acid-free albumin, $10 \mathrm{mM}$ Tris, $\mathrm{pH}$ 7.4). Then, the tissue was weighed, finely minced, and washed with HM. Finally, liver fragments were gently homogenized $(20 \% \mathrm{w} / \mathrm{v})$ in HM using a glass Potter-Elvehjem homogenizer set at a standard velocity $(500 \mathrm{rpm})$ for $1 \mathrm{~min}$. Aliquots of liver homogenates were used for analytical procedures and preparation of mitochondrial fractions.

\subsection{Preparation of mitochondrial fraction}

The homogenates, diluted 1:1 with HM, were freed of debris and nuclei by centrifugation at $500 \mathrm{~g}$ for 10 $\min$ at $4^{\circ} \mathrm{C}$. The resulting supernatants were centrifuged at $10,000 \mathrm{~g}$ for $10 \mathrm{~min}$. The mitochondrial pellets were washed twice with isolation medium (IM) $(220 \mathrm{mM}$ mannitol, $70 \mathrm{mM}$ sucrose, $1 \mathrm{mM}$ EGTA, $20 \mathrm{mM}$ Tris, $\mathrm{pH}$ 7.4), resuspended in the same solution and used for determination of analytical procedures.

The protein content of liver preparations was determined, upon solubilization in $0.5 \%$ deoxycholate, by the biuret method (Gornall et al., 1949) with bovine serum albumin as standard.

\subsection{Oxygen consumption}

Oxygen consumption of liver homogenates was monitored at $30^{\circ} \mathrm{C}$ by a Gilson respirometer in $1.6 \mathrm{ml}$ of incubation medium (145 mM KCl, $30 \mathrm{mM}$ Hepes, 5 mM KH $\mathrm{KH}_{2} \mathrm{PO}, 3 \mathrm{mM} \mathrm{MgCl}, 0.1 \mathrm{mM}$ EGTA, pH 7.4) with $50 \mu \mathrm{l}$ of homogenate and succinate $(10 \mathrm{mM})$, plus $5 \mu \mathrm{M}$ rotenone $($ Rot $)$, or pyruvate/malate $(10 / 2.5$ $\mathrm{mM}$ ) as substrates, in the absence (State 4) and in the presence (State 3) of $500 \mu \mathrm{M}$ ADP. Mitochondrial State 4 and State 3 respiration was monitored by the same method using $0.25 \mathrm{mg}$ of mitochondrial protein per $\mathrm{ml}$ in the presence of Complex I- and Complex II-linked substrates.

\subsection{Activity of complexes of respiratory chain}


The first three complexes of the electron transport system were measured by spectrophotometric methods (Ragan et al., 1987) using a Beckman (Fullerton CA USA) model DU 640. Complex IV (cytochrome c oxidase) activity was determined by a polarographical procedure at $30^{\circ} \mathrm{C}$ (Barré et al., 1987) using a Gilson glass respirometer equipped with a Clark oxygen electrode (Yellow Springs Instruments Ohio USA).

\subsection{Cytochrome oxidase activity and mitochondrial protein content}

Cytochrome c oxidase (COX) activity of homogenates was also determined and the ratio between the cytochrome oxidase activities in homogenates and mitochondria supplied rough estimates of hepatic content of mitochondrial proteins. Moreover, because the in vitro activity of COX is positively correlated to the maximal oxygen consumption (Simon and Robin, 1971), it was also used as a measure of the aerobic metabolic capacity of tissues.

\subsection{Mitochondrial protein SDS-PAGE}

SDS-PAGE was performed according to Laemmli (Laemmli, 1970), using a 10\% acrylamide as resolving gel. Samples were prepared by diluting $10 \mu \mathrm{l}$ of mitochondrial suspension containing $1.5 \mathrm{mg} / \mathrm{ml}$ of protein with $5 \mu \mathrm{l}$ of $3 \%$ SDS, 30\% glycerol, $15 \%$ b-mercaptoethanol $0.1 \%$ bromophenol blue, $0.187 \mathrm{M}$ Tris base, pH 6.8 and were boiled for 5 min before loading on the gel. Gel was run in the mini protean equipment (BioRad) for about $1 \mathrm{hr}$ at constant voltage $(25 \mathrm{~V})$. The gel upon electrophoresis was fixed with $25 \%$ isopropanol-10\% acetic acid and stained with the same solution containing 0.02\% Coomassie G-250; destaining was obtained by shaking the gels for $48 \mathrm{hr}$ in $10 \%$ acetic acid.

\subsection{RNA isolation}

Total RNA was extracted from livers following Chomczynski and Sacchi (Chomczynski and Sacchi, 1987). The yield and quality of RNA were assessed by the $260 / 280 \mathrm{~nm}$ optical density ratio and by electrophoresis under non-denaturing conditions on 1.8\% agarose gel. Ambion's DNA-freeTM kit (Ambion Europe Ltd., UK) was used to remove contaminating DNA from RNA preparations. Then, $2.0 \mu \mathrm{g}$ of total RNAs in $20 \mu$ l total volume were retro-transcribed to obtain cDNA using Superscript II Reverse 
Transcriptase kit (Invitrogen, San Giuliano Milanese, Italy), following manufacturer's instructions. cDNA preparation was used to perform Real Time PCR analysis.

\subsection{Real time quantitative PCR}

Real Time PCR reactions were performed on the DNA Engine Opticon 2 System (MJ Research, Boston, MA) in $20 \mu \mathrm{l}$ total volume with $4 \mu \mathrm{l}$ of the cDNA sample, obtained diluting (1:30) cDNA preparation, and $0.3 \mu \mathrm{M}$ of each primer using the DyNAmo ${ }^{\mathrm{TM}} \mathrm{HS}$ SYBR ${ }^{\circledR}$ Green qPCR Kit (Finnzymes, Espoo, Finland), according to the manufacturer's instructions. Primers (PRIMM Biotech Products and Services, Milan, Italy) used for the amplification, designed using Primer3 software (Rozen and Skaletsky, 2000), were: NRF-1 forward, 5'-aaattgggccacattacaggg-3'; NRF-1 reverse, 5'-gttgcatctcctgagaagcg-3'; NRF-2 $\alpha 1$ forward, 5'gggaggtggatgtaatgtgg-3'; NRF-2 a1 reverse, 5'-tgggcctggaactacaactc-3'; $\quad$ PGC-1forward, 5'cgcagagagtatgagaagcg-3'; $\quad$ PGC-1 reverse, $\quad 5^{\prime}$-aagcgtcacaggtgtaacgg-3'; $\quad \beta$-actin forward, $5^{\prime}$ gccaaccgtgaaaagatgac-3'; $\beta$-actin reverse, 5'-agcgcgtaaccctcatagat-3'. Data normalization was performed using $\beta$-actin as housekeeping gene. The amplification protocol was as follows: 1 cycle of 15 min at $95{ }^{\circ} \mathrm{C}$, 39 cycles of $95{ }^{\circ} \mathrm{C}$ for $15 \mathrm{~s}, 56{ }^{\circ} \mathrm{C}$ (annealing for PGC-1 gene primers), $58{ }^{\circ} \mathrm{C}$ (annealing for NRF-1 gene primers), and $64.0{ }^{\circ} \mathrm{C}$ (annealing for NRF-2 gene primers), for $20 \mathrm{~s}, 72{ }^{\circ} \mathrm{C}$ for $20 \mathrm{~s}$, plus an extension at 72 ${ }^{\circ} \mathrm{C}$ for $5 \mathrm{~min}$.

Experiments were carried out in duplicates or triplicates. The relative expression value of treated rats with respect to hypothyroid rat signal value was calculated as fold change with the formula $2^{-\Delta \Delta C t}$. For each value four independent experiments were performed.

\subsection{Western blotting}

Liver fragments were gently homogenized $(1: 10, \mathrm{w} / \mathrm{v})$ in $500 \mathrm{mM} \mathrm{NaCl}, 0.5 \%$ nonidet $\mathrm{P}-40,6 \mathrm{mM}$ EDTA, 6 mM EGTA, $1 \mathrm{mM}$ dithiotreitol, $40 \mathrm{mM}$ Tris-HCl, $\mathrm{pH} 8.0$, in the presence of antiprotease mixture including $40 \mu \mathrm{g} / \mathrm{ml}$ PMSF, $5 \mu \mathrm{g} / \mathrm{ml}$ leupeptin, $5 \mathrm{~g} / \mathrm{ml}$ aprotinin, $7 \mathrm{~g} / \mathrm{ml}$ pepstatin. Homogenates were centrifuged at $1000 \mathrm{~g}$ for $10 \mathrm{~min}$ at $4{ }^{\circ} \mathrm{C}$ and resulting supernatants were electrophoresed through $6 \%$ stacking and 12\% running SDS-PAGE gel as previously described for mitochondrial proteins. Separated hepatic 
proteins were transferred to nitrocellulose membranes by electroblotting. Membranes were incubated with a 1:1000 dilution of antibodies to PGC-1, NRF-1, and NRF-2 (Santa Cruz Biotechnology, Santa Cruz, CA, USA) in $154 \mathrm{mM} \mathrm{NaCl}, 10 \mathrm{mM}$ Tris-HCl, pH 8.0, 2.5\% non-fat dry milk, 10\% Tween 20. Rabbit polyclonal antibodies raised against amino acids 1-300 mapping near the N-terminus of PGC-1, 204-503 mapping at the C-terminus of NRF-1, and 1-180 of NRF-2 $\alpha$, were used. Antibody binding was detected by carrying out secondary antibody incubations using peroxidase-conjugated anti first IgG antibodies (Santa Cruz Biotechnology) diluted 1:4000. Secondary antibody was detected using the ECL system according to the manufacturer's recommendation (Santa Cruz Biotechnology). The blots were stripped by treating them for 10 min with $0.2 \mathrm{M} \mathrm{NaOH}$ followed by 5-min wash with $\mathrm{H}_{2} \mathrm{O}$ and two 5-min washes with $154 \mathrm{mM} \mathrm{NaCl}, 10$ $\mathrm{mM}$ Tris- $\mathrm{HCl}, \mathrm{pH} 8.0,0.1 \%$ Tween 20. The blots were again blocked for $30 \mathrm{~min} 154 \mathrm{mM} \mathrm{NaCl}, 10 \mathrm{mM}$ Tris-HCl, $\mathrm{pH} 8.0,2.5 \%$ non-fat dry milk, 10\% Tween 20T, washed as above, and incubated for $2 \mathrm{~h}$ with a 1:2000 dilution of anti-actin antibody (Santa Cruz Biotechnology) in blocking solution. Remaining procedures, as described for other antibodies, were followed. The actin was used for loading standardization. To compare protein expression levels among groups, a standard hypothyroid sample was run on each gel and all group values were then compared with the hypothyroid sample that was assigned a value of 1 .

\subsection{Data analysis}

The data, expressed as means + standard error, were analyzed with a one-way analysis of variance method. When a significant $\mathrm{F}$ ratio was found, the Student-Newman-Keuls multiple range test was used to determine the statistical significance between means. Probability values $(\mathrm{P})<0.05$ were considered significant. In Fig. 2 the results of the experiments are presented as sample curves.

\section{Results}

Changes in thyroid state were documented by modifications in heart weight/body weight ratio, and plasma levels of $\mathrm{FT}_{3}$ and $\mathrm{FT}_{4}$. The body weights, which were $243 \pm 10,239 \pm 10,239 \pm 7$, and $257 \pm 6 \mathrm{~g}$ for $\mathrm{H}$, $\mathrm{HT}_{4}, \mathrm{HT}_{3}$, and $\mathrm{HT}_{3}+\mathrm{CE}$ rats, respectively, were not significantly affected $(\mathrm{P}>0.05)$ by cold exposure and hormonal treatment. Conversely, the heart weight increased differently in hyperthyroid rats so that such 
animals exhibited a heart/body weight ratio increased in comparison to the controls $(2.17 \pm 0.04)$. The ratio was significantly lower $(\mathrm{P}<0.05)$ in $\mathrm{T}_{4}$-treated $(2.50 \pm 0.04)$ than in both groups of $\mathrm{T}_{3}$-treated rats $(3.18 \pm 0.17$ and 3.10 \pm 0.06 for $\mathrm{HT}_{3}$ and $\mathrm{HT}_{3}+\mathrm{CE}$ rats, respectively). As shown in Fig. 1, plasma levels of $\mathrm{FT}_{3}$ were higher in both groups of $\mathrm{T}_{3}$-treated rats, whereas $\mathrm{FT}_{4}$ levels were higher in $\mathrm{T}_{4}$-treated rats.

\subsection{Oxygen consumption}

Data on rates of both succinate- and pyruvate/malate-supported oxygen consumption by liver preparations are offered in Fig. 2. Such rates were increased by hormonal treatment in homogenates during both state 4 and state 3 respirations irrespective on substrate. The lowest rates were reached in $\mathrm{HT}_{4}$ group, whereas the highest ones were reached in $\mathrm{HT}_{3}+\mathrm{CE}$ group.

During mitochondrial state 4 respiration, all rates were increased by hormonal treatment irrespective of substrate and reached the lowest and highest values in $\mathrm{HT}_{4}$ and in $\mathrm{HT}_{3}$, respectively. During state 3 respiration, all rates were also increased in treatment groups. However, in the presence of succinate they reached the highest values in $\mathrm{HT}_{3}$ group and were not different in $\mathrm{HT}_{4}$ and $\mathrm{HT}_{3}+\mathrm{CE}$ groups, whereas in the presence of pyruvate/malate the rates reached the highest values in $\mathrm{HT}_{3}$ and $\mathrm{HT}_{3}+\mathrm{CE}$ groups.

\subsection{Activity of complexes of respiratory chain}

As shown in Fig. 3, the activity of Complex I was increased by $\mathrm{T}_{4}$ treatment and in the greater measure by $\mathrm{T} 3$ treatment irrespective of cold exposure. Even the activity of Complex II was differently increased by $\mathrm{T}_{4}$ and $\mathrm{T}_{3}$ treatment, but cold exposure of $\mathrm{HT}_{3}$ rats made such an activity no significantly different from that of $\mathrm{HT}_{4}$ rats. The activities of Complex III and Complex IV were increased in all treatment groups, but the highest values were obtained in $\mathrm{HT}_{3}$ group and the lowest ones in $\mathrm{HT}_{4}$ group.

\subsection{Cytochrome oxidase activity and mitochondrial protein content}

As shown in Fig. 4, hormonal treatments were associated with increases in COX activities in homogenates, which were lower in $\mathrm{HT}_{4}$ than in $\mathrm{HT}_{3}$ rats. The cold exposure of $\mathrm{T}_{3}$-treated rats was associated 
with further increase of homogenate COX activity. Liver mitochondrial protein content was not modified by hormonal treatment, but was increased when $\mathrm{T}_{3}$ treatment was associated with cold exposure.

\subsection{Mitochondrial protein analysis}

The results concerning SDS-PAGE analysis of mitochondrial proteins are reported in Fig. 5. It is apparent that the treatments differentially affect the mitochondrial protein profile. In particular, the profile showed by $\mathrm{HT}_{4}$ and $\mathrm{HT}_{3}+\mathrm{CE}$ groups differs from that showed by $\mathrm{HT}_{3}$ group in a band around approximately $95 \mathrm{kDa}$ and in a band above $116 \mathrm{kDa}$.

\section{5. mRNA expression}

As the m-RNA expression levels were too low for suitable northern blot analyses (data not shown), we performed quantitative Real Time PCR. As shown in Fig. 6, PGC-1 expression levels were increased in all treatment groups. The increases were moderate in $\mathrm{T}_{4}$ - and $\mathrm{T}_{3}$-treated rats (3.5-fold) and more high (9-fold) in $\mathrm{T}_{3}$-treated and cold exposed rats. Different pattern was obtained for NRF-1 and NRF-2 expression levels. Indeed, NRF-1 expression reached higher levels only in $T_{3}$ treated rats and was restored to hypothyroid levels after cold exposure. Levels of NRF-2 expression were decreased by treatments, but they were lower in $\mathrm{HT}_{4}$ than in $\mathrm{HT}_{3}$ and $\mathrm{HT}_{3}+\mathrm{CE}$ rats.

\subsection{Protein expression}

In order to verify whether modified concentrations of mRNA molecules also lead to similar directional changes in protein abundance, we performed an analysis by western blot. Western blot experiments were conducted using identical amounts of total protein extract from livers of hypothyroid and treated rats that were loaded onto an SDS-PAGE, and blotted according to standard protocols. The high specificity of the antibodies and the molecular weight markers allowed us to easily identify the NRF-1, and NRF-2 proteins. The specificity of the PGC-1 antibody was relatively lower, but the protein was clearly identified by its molecular weight. 
The results reported in Fig. 7 show that PGC-1, NRF-1, and NRF-2 levels were increased by $\mathrm{T}_{4}$ treatment and in greater measure by $\mathrm{T}_{3}$ treatments. Cold exposure of $\mathrm{T}_{3}$-treated rats produced further increase in PGC-1 and NRF-2 levels, so that they were significantly higher than those found in $\mathrm{HT}_{4}$ and $\mathrm{HT}_{3}$ rats. Conversely, NRF-1 levels were reduced to values not significantly different than those found in $\mathrm{HT}_{4}$ group.

We wanted to establish whether there is a relationship between protein levels and COX activities in treatment groups. Thus we found that treatment-evoked changes in PGC-1 and NRF-2 protein expression were matched by parallel changes in COX activity Conversely, no relationship was found between NRF-1 protein expression and COX activity (Fig. 8). 


\section{Discussion}

The iodothyronine role in the liver response to cold was previously investigated comparing such a response with those elicited by euthyroid rat treatments with $T_{3}$ or $T_{4}$ (Venditi et al., 2006a). The present protocol allows to compare metabolic characteristics of rats whose serum substantially contains either $\mathrm{T}_{4}$ or $T_{3}$. It also allows to investigate the possible synergic effects of $T_{3}$ and catecholamines, because, plasma noradrenaline levels, which are low or normal in hyperthyroidism (Stoffer et al., 1973), remarkably increase during cold exposure (Storm et al., 1981; Peralta et al., 2003).

Thyroid hormone actions are mediated by controlling the expression of specific genes through binding to nuclear thyroid hormone receptors. The affinity of $T_{3}$ analogs for such receptors is correlated to their biological activity (Koerner et al., 1975), so that observation that $\mathrm{T}_{4}$ and $\mathrm{T}_{3}$ differentially increase aerobic capacity of liver preparations agrees with the lower affinity of $\mathrm{T}_{4}$ for hepatic nuclear sites (Koerner et al., 1975). We also found that cold exposure of $T_{3}$-treated rats further increases homogenate aerobic capacity, whereas decreases the mitochondrial one. The cold-linked changes were associated with enhancement in tissue content of mitochondrial proteins which was not modified by hormonal treatment. This result is consistent with previous observations that $T_{3}$ does not modify number (Goglia et al., 1989) and protein mass (Venditti et al., 2006a) of liver mitochondria, whereas cold induces mitochondrial proliferation (Goglia et al., 1983; Goglia et al., 1985) and increases mitochondrial protein content (Venditti et al., 2004; Venditti et al., 2006a). On the other hand, our results do not support the previous hypothesis (Venditti et al., 2006a) that thyroxine is a factor responsible for cold-linked mitochondrial proliferation. Indeed, $\mathrm{T}_{4}$ treatment does not increase mitochondrial proteins that, conversely, are increased by cold exposure of $\mathrm{T}_{3}$-treated rats in which $\mathrm{T}_{4}$ plasma levels are low.

The modifications induced by treatments in the in vitro State 3 oxygen consumption by liver preparations were consistent enough with the changes in aerobic capacities. However, cold exposure of $\mathrm{T}_{3}$-treated rats lowered mitochondrial COX activity of about $8 \%$, decreased succinate-sustained mitochondrial respiration in greater measure (about 24\%) and did not modify that sustained by pyruvate/malate. These results are consistent with observation that cold exposure of euthyroid rats increases liver mitochondrial respiration less than $\mathrm{T}_{3}$ treatment, although the serum $\mathrm{FT}_{3}$ levels are not different, and cold-induced increases are different in the presence of succinate (10\%) and pyruvate/malate (45\%) (Venditti et al., 2006b). Our previous and 
present data suggest that cold exposure differentially affects respiratory chain components. This idea is supported by finding that cold exposure of $\mathrm{T}_{3}$-treated rats decreases the activities of all multi-subunit complexes other than Complex I. In the light of the enhanced mitochondrial protein content, the above finding also indicates that hepatic levels of Complex I components increase following cold exposure. The ability of cold exposure to differentially regulate mitochondrial components was also shown by SDS-PAGE analysis of mitochondrial proteins, which, in particular, confirmed previous report that cold exposure, but not $\mathrm{T}_{3}$, increases the concentration of a component with molecular weight higher than $116 \mathrm{kDa}$ (Venditti et al., 2006b). These results indicate that in cold-exposed rats factors are operative which are involved in proliferation of mitochondria and differential induction of respiratory chain components. On the other hand, it seems that $T_{3}$, although does not induce mitochondrial proliferation, is able to increase the mitochondrial concentration of respiratory chain components in agreement with early observation that thyroid hormone administration selectively increases the area of the mitochondrial inner membranes (Jakovcic et al., 1978). It is, however, possible that mitochondrial proliferation requests the concomitant action of more than one factor and $\mathrm{T}_{3}$ contributes to phenomenon in conditions, such as cold exposure, in which additional factor is present. Several reports support the idea that such an additional factor can be the noradrenaline.

The expression of respiratory apparatus is controlled by nuclear regulatory proteins including nuclear respiratory factors 1 and 2 (NRF-1 and NRF-2), and the peroxisomal proliferator-activated receptor- $\gamma$ coactivator (PGC-1). NRF-1 and NRF-2 are transcriptional factors which have been linked to the transcriptional control of many genes involved in mitochondrial function and biogenesis (Scarpulla, 2002). PGC-1 is a transcriptional coactivator which appears to play a role as an intermediary between environmental stimuli and transcriptional responses (Scarpulla, 2002).

It has been shown that $T_{3}$ triggers processes, such as mitochondrial biogenesis, adaptive thermogenesis and hepatic gluconeogenesis (Yen, 2001), which resemble those regulated by PGC-1, which, in turn, interacts with several nuclear hormone receptors including thyroid hormone receptor $\beta$ (Puigserver et al., 1998). It has also been reported that liver PGC-1 and NRF-1 mRNA expression levels increase $6 \mathrm{~h}$ after $\mathrm{T}_{3}$ treatment of hypothyroid rats and remains high for different periods (42 and $18 \mathrm{~h}$, respectively). Conversely, NRF-2 expression levels do not change within the first $24 \mathrm{~h}$ and decrease after $48 \mathrm{~h}$ (Weitzel et al., 2001). Subsequently, $\mathrm{T}_{3}$ treatment has been found to increase liver PGC-1 protein level in measure lower than 
mRNA level (Weitzel et al., 2003). Increases of different extent in PGC-1 mRNA and protein levels (4.5 and 2.3 fold, respectively) have also been found $24 \mathrm{~h}$ after $\mathrm{T}_{3}$ addition to hepatocytes (Zhang et al., 2004). Significant increases in PGC-1 protein levels after $T_{3}$ treatment ( 5 days) have been found in a variety of tissues, including liver (Irrcher et al., 2003). Although recent report indicates that thyroid hormone-mediated gene expression patterns are not completely depending on PGC-1 activation (Wulf et al., 2007), the above data support the idea that a thyroid hormone-mediated activation of PGC-1 might help this coactivator to exert its function in adaptation to endocrine signals. On the other hand, additional factors might contribute to PGC-1 activation in response to other signals, such as low environmental temperature. Indeed, PGC-1 mRNA is induced in the mouse brown fat by cold and $\beta$-adrenergic agonist treatment which mimics the coldinduced sympathetic innervation of brown fat (Puigserver et al., 1998), supporting the view that PGC-1 is a transcriptional coactivator of adaptive thermogenesis. To illustrate how PGC-1 can link the external environment to mitochondrial biogenesis and gene expression a model has been proposed in which noradrenaline, released following cold exposure, leads to PGC-1 expression induction through elevation of cellular cAMP (Wu et al., 1999).

In the light of the aforementioned results, we measured mRNA levels of PGC-1, NRF-1, and NRF-2 to better understand transcript levels and their regulation on cold-induced changes in rat liver mitochondrial population. Thus, we found that only PGC-1 levels are related to cytochrome oxidase activity, respiratory characteristics, and mitochondrial protein content in liver homogenates. However, investigations of the steady-state level of mRNA concentrations are hampered by the question of whether modulation of the mRNA concentration also reflects a modulation of the protein concentration. Hence, we also tested PGC-1, NRF-1, and NRF-2 protein expression levels and found patterns of protein expression different from those of mRNA expression. PGC-1 protein expression pattern was similar enough to that of mRNA expression, but the cold-induced increase in protein levels was much lower than that in mRNA levels. Moreover, NRF-1 proteins levels reached the highest value in $\mathrm{T}_{3}$-treated group, but levels in $\mathrm{T}_{4}$-treated and cold-exposed rats were significantly higher than controls. Finally, the pattern of NRF-2 protein was completely different from that of mRNA, because protein levels in all treatment groups were higher than controls and the highest values were found in cold exposed rats. We are not able to explain the differences found in treatment effects on levels of NRF-1 mRNA and protein expression. Conversely, the results concerning NRF-2 levels are 
consistent with the reported lack of a correlation between NRF-2 mRNA and protein levels in rat tissues, which has suggested that NRF-2 expression may be regulated by a posttranscriptional mechanism (Vallejo et al., 2000).

The changes in protein expression levels appear to match better with the treatment-linked metabolic modifications. In fact, our data show that hormonal treatment induces PGC-1 protein expression, which occurs coincident with increases in transcription factor expression and oxidative capacity. However, they are not able to supply an exhaustive explanation of the changes induced by treatments in characteristics of mitochondrial population. In agreement with previous observations (Irrcher et al., 2003), we found that the changes induced by treatments in PGC-1 protein expression are largely matched by parallel changes in COX activity. Similar pattern was also found for NRF-2 protein expression. Because thyroid hormone increases expression of mitochondrial and nuclear encoded subunits of COX in rat liver (Sheehan et al., 2004), it is conceivable that PGC-1 and NRF-2 protein expression also correlates with COX protein concentration. Conversely, no relationship was found between NRF-1 levels and COX activities, because of the unexpected fall in NRF-1 levels following cold exposure of $T_{3}$-treated rats. This result disagrees with the previous observation that biogenesis of muscle mitochondria stimulated by PGC-1 requires the function of NRF-1 (Wu et al., 1999). On the other hand, the finding that cold-induced increase in COX activity in zebrafish muscle is associated with increased NRF-1 mRNA levels, but unmodified PGC-1 mRNA levels (McClelland e al., 2006) suggests that the regulatory proteins and the mechanisms involved in mitochondrial biogenesis can be species and tissue-dependent.

In conclusion, our data supply strong indication that PGC-1 and NRFs are responsible for the increases, induced by hormonal treatment, in respiratory chain components. Conversely, other investigation needs to clarify their possible role in cold-induced mitochondrial proliferation in rat liver.

\section{Acknowledgements}

This work was supported by grants from the Italian Ministry of University and Scientific and Technological Research. 


\section{References}

Barker, S.B., Klitgaard, H.M., 1952. Metabolism of tissues excised from thyroxine-injected rats. Am. J. Physiol. 170, 81-86.

Barré, H., Bailly, L., Rouanet, J.L., 1987. Increased oxidative capacity in skeletal muscles from acclimated ducklings: A comparison with rats. Comp. Biochem. Physiol. 88B, 519-522.

Cageao, L.F., Mignone, I.R., Ricci, C.R., Brignone, C.C., Brignone, J.A., Zaninovich, A.A., 1992. Effects of thyroid hormones on mitochondrial oxygen consumption in brown adipose tissue and heart from cold exposed hypothyroid rats. Acta Endocrinol. 127, 72-75.

Chomczynski, P., Sacchi. N., 1987. Single-step method of RNA isolation by acid guanidinium thyocyanatephenol-chloroform extraction. Anal. Biochem. 162, 156-159.

Fernández, V., Barrientos, X., Kipreos, K., Valenzuela, A., Videla, LA., 1985. Superoxide radical generation, NADPH oxidase activity, and cytochrome P-450 content of rat liver microsomal fraction in an experimental thyroid state: relation to lipid peroxidation. Endocrinology 117, 496-501.

Goglia, F., Liverini, G., De Leo, T., \& Barletta, A., 1983. Thyroid state and mitochondrial population during cold exposure. Pflügers Arch. Eur. J. Physiol. 396, 49-53.

Goglia, F., Liverini, G., Lanni, A., Bottiglieri, S., Barletta, A., 1985. Alteration in hepatic mitochondrial compartment of cold-acclimated rats. Association with enhanced triiodothyronine serum levels. A morphometric/stereologic study by electron microscopy. Exp. Biol. 44, 41-56.

Goglia, F., Liverini, G., Lanni, A., Iossa, S., Barletta, A., 1989. The effect of thyroid state on respiratories activities of three rat liver mitochondrial fractions. Mol. Cell. Endocrinol. 62, 41-46.

Gornall, A.G., Bardawill, C.J., David, M.M., 1949. Determination of serum proteins by mean of the biuret reaction. J. Biol. Chem. 177, 751-766.

Guernsey, D.L., Stevens, E.D., 1977. The cell membrane sodium pump as a mechanism for increasing thermogenesis during cold acclimation in rats. Science 196, 908-910.

Irrcher, I., Adhihetty, P.J., Sheehan, T., Joseph, A.M., Hood, D.A., 2003. PPARgamma coactivator-1alpha expression during thyroid hormone- and contractile activity-induced mitochondrial adaptations. Am. J. Physiol. 284, 1669-1677.

Jacovcic, S., Swift, H.H., Gross, N.J., Rabinowitz, M., 1978. Biochemical and stereological analysis of rat liver mitochondria in different thyroid states. J. Cell Biol. 77, 887-901.

Koerner, D., Schwartz, H.L., Surks, M.I., Oppenheimer, J.H., Jorgensen, E.C., 1975. Binding of selected iodothyronine analogues to receptor sites of isolated rat hepatic nuclei. J. Biol. Chem. 250, 417-6423.

Laemmli, U.K., 1970. Cleavage of structural proteins during the assembly of the head of bacteriophage T4. Nature 227, 680-685.

McClelland, G.B., Craig, P.M., Dhekney, K., Dipardo, S., 2006. Temperature- and exercise-induced gene expression and metabolic enzyme changes in skeletal muscle of adult zebrafish (Danio rerio). J. Physiol. 577, 739-751. 
Obregon, M.J., Pascual, A., Mallol, J., Morreale de Escobar, G., Escobar del Rey, F., 1980. Evidence against a major role of L-thyroxine at the pituitary level: studies in rats treated with iopanoic acid (telepaque). Endocrinology 106, 1827-1836.

Peralta, J.G., Finocchietto, P.V., Converso, D., Schöpfer, F., Carreras, M.C., Poderoso, J.J., 2003. Modulation of mitochondrial nitric oxide synthase and energy expenditure in rats during cold acclimation. Am. J. Physiol. 284, H2375-H2383.

Puigserver, P., Wu, Z., Park, C.W., Graves, R., Wright, M., Spiegelman, B.M., 1998. A cold-inducible coactivator of nuclear receptors linked to adaptive thermogenesis. Cell 92, 829-839.

Ragan, C.I., Wilson, M.T., Darley-Usmar, V.M., Lowe, P.N., 1987. Sub-fractionation of mitochondria and isolation of the proteins of oxidative phosphorylation. In: Darley-Usmar V.M., Rickwood D., Wilson M.T. (eds.), Mitochondria: A practical approach. IRL Press, Oxford, pp. 79-112.

Rozen, S., Skaletsky, H.J., 2000. Primer3 on the WWW for general users and for biologist programmers. In: Krawetz, S., Misener, S. (eds.), Bioinformatics methods and protocols: Methods in molecular biology. Humana Press, Totowa, NJ, pp. 365-386.

Scarpulla, R.C., 2002. Nuclear activators and coactivators in mammalian mitochondrial biogenesis. Biochim. Biophys. Acta 1576, 1-14.

Seitz, H.J., Muller, M.J., Soboll, S., 1985. Rapid thyroid hormone effect on mitochondrial and cytosolic ATP/ADP ratios in the intact liver cell. Biochem. J. 277, 149-153.

Sheehan, T.E., Kumar, P.A., Hood, D.A., 2004 Tissue specific regulation of cytochrome c oxidase subunit expression by thyroid hormone. Am. J. Physiol 286, E968-E974.

Shiota, M., Tanaka, T., Sugano, T., 1985. Effect of norepinephrine on gluconeogenesis in perfused livers of cold-exposed rats. Am. J. Physiol. 249, 281-286.

Simon, L.M., Robin, E.D., 1971. Relationship of cytochrome oxidase activity to vertebrate total and organ oxygen consumption. International J. Biochem. 2, 560-573.

Stoffer, S.S., Jiang, N.S., Gorman, C.A., Picker, G.M., 1973. Plasma catecholamines in hypothyroidism and hyperthyroidism. J. Clin. Endocrinol. Metab. 36, 587-589.

Storm, H., van Hardelved, C., Kassenaar, A.A.H., 1981. Thyroid hormone-catecholamines interrelationship during exposure to cold. Acta Endocrinol. 97, 91-97.

Vallejo, C.G., Escrivá, H., Rodríguez-Peňa, A., 2000. Evidence of tissue-specific, post-transcriptional regulation of NRF-2 expression. Biochimie 82, 1129-1133.

Venditti, P., De Rosa, R., Portero-Otin, M., Pamplona, R., Di Meo, S., 2004. Cold-induced hyperthyroidism produces oxidative damage in rat tissues and increases susceptibility to oxidants. Int. J. Biochem. Cell Biol. 36, 1319-1331.

Venditti, P., Pamplona, R., Ayala, V., De Rosa, R., Caldarone, G., Di Meo, S., 2006a. Differential effects of experimental and cold-induced hyperthyroidism on factors inducing rat liver oxidative damage. J. Exp. Biol. 209, 817-825. 
Venditti, P., Pamplona, R., Portero-Otin, M., De Rosa, R., Di Meo, S., 2006b. Effect of experimental and cold-exposure induced hyperthyroidism on $\mathrm{H}_{2} \mathrm{O}_{2}$ production and susceptibility to oxidative stress of rat liver mitochondria. Archiv. Biochem. Biophys. 447, 11-22.

Weitzel, J.M., Hamann, S., Jauk, M., Lacey, M., Filbry, A., Radtke, C., Iwen, K.A.H., Kutz, S., Harneit, A., Lizardi, P.M., Seitz, H.J., 2003. Hepatic gene expression patterns in thyroid hormone-treated hypothyroid rats. J. Mol. Endocrinol. 31, 291-303.

Weitzel, J.M., Radtke, C., Seitz, H.J., 2001. Two thyroid hormone-mediated gene expression patterns in vivo identified by cDNA expression arrays in rat. Nucleic Acids Res. 29, 5148-5155.

Wu, Z., Puigserver, P., Andersson, U., Zhang, C., Adelmant, G., Mootha, V., Troy, A., Cinti, S., Lowell, B., Scarpulla, R.C., Spiegelman, B.M., 1999, Mechanisms controlling mitochondrial biogenesis and function through the thermogenic coactivator PGC-1. Cell 98, 115-124.

Wulf, A., Harneit, A., \& Weitzel, J.M., 2007. T 3 -mediated gene expression is independent of PGC-1alpha. Mol. Cell. Endocrinol. 270, 57-63.

Yen, P.M., 2001. Physiological and molecular basis of thyroid hormone action. Physiol. Rev. 81, 10971142.

Zaninovich, A.A., Rebagliati, I., Raíces, M., Ricci, C., Hagmüller, K., 2003. Mitochondrial respiration in muscle and liver from cold-acclimated hypothyroid rats. J. Appl. Physiol. 95, 1584-1590.

Zhang, Ti., Ma, Ke., Song, S., Elam, M.B., Cook, G.A., Park, E.A, 2004. Peroxisomal proliferators activated receptor- $\gamma$ coactivator-1 $\alpha$ (PGC-1 $\alpha$ ) enhances the thyroid hormone induction of carnitine palmitoyltransferase I (CPT-I $\alpha$ ). J. Biol. Chem. 279, 53963-53971. 


\section{Figure Legends}

Figure 1. Serum levels of free triiodothyronine $\left(\mathrm{FT}_{3}\right)$ and thyroxine $\left(\mathrm{FT}_{4}\right)$ in hypothyroid $(\mathrm{H})$, hypothyroid $\mathrm{T}_{4}{ }^{-}$ treated $\left(\mathrm{HT}_{4}\right)$, hypothyroid $\mathrm{T}_{3}$-treated $\left(\mathrm{HT}_{3}\right)$, and hypothyroid $\mathrm{T}_{3}$-treated and cold-exposed $\left(\mathrm{HT}_{3}+\mathrm{CE}\right)$ rats.

Values are means \pm S.E.M. For each value eight rats were used. ${ }^{a}$ significant vs. $\mathrm{H}$ rats; ${ }^{\mathrm{b}}$ significant vs. $\mathrm{HT}_{4}$ rats. The level of significance was chosen as $P<0.05$.

Fig. 2. Rates of oxygen consumption by liver homogenates and mitochondria from hypothyroid $(\mathrm{H})$, hypothyroid $\mathrm{T}_{4}$-treated $\left(\mathrm{HT}_{4}\right)$, hypothyroid $\mathrm{T}_{3}$-treated $\left(\mathrm{HT}_{3}\right)$, and hypothyroid $\mathrm{T}_{3}$-treated and cold-exposed $\left(\mathrm{HT}_{3}+\mathrm{CE}\right)$ rats.

Values are means \pm S.E.M. For each value eight rats were used. ${ }^{a}$ significant vs. $\mathrm{H}$ rats; ${ }^{\mathrm{b}}$ significant vs. $\mathrm{HT}_{4}$ rats; ${ }^{\mathrm{c}}$ significant vs. $\mathrm{HT}_{3}$ rats. The level of significance was chosen as $P<0.05$.

Fig. 3. Activities of mitochondrial respiratory complexes in liver from hypothyroid $(\mathrm{H})$, hypothyroid $\mathrm{T}_{4}$-treated $\left(\mathrm{HT}_{4}\right)$, hypothyroid $\mathrm{T}_{3}$-treated $\left(\mathrm{HT}_{3}\right)$, and hypothyroid $\mathrm{T}_{3}$-treated and cold-exposed $\left(\mathrm{HT}_{3}+\mathrm{CE}\right)$ rats.

Values are means \pm S.E.M. For each value eight rats were used. ${ }^{a}$ significant vs. $\mathrm{H}$ rats; ${ }^{\mathrm{b}}$ significant vs. $\mathrm{HT}_{4}$ rats; ${ }^{\mathrm{c}}$ significant vs. $\mathrm{HT}_{3}$ rats. The level of significance was chosen as $P<0.05$.

Fig. 4. Cytochrome oxidase (COX) activity and mitochondrial protein content in liver from hypothyroid (H), hypothyroid $\mathrm{T}_{4}$-treated $\left(\mathrm{HT}_{4}\right)$, hypothyroid $\mathrm{T}_{3}$-treated $\left(\mathrm{HT}_{3}\right)$, and hypothyroid $\mathrm{T}_{3}$-treated and cold-exposed $\left(\mathrm{HT}_{3}+\mathrm{CE}\right)$ rats.

Values are means \pm S.E.M. For each value eight rats were used. ${ }^{a}$ significant vs. $\mathrm{H}$ rats; ${ }^{\mathrm{b}}$ significant vs. $\mathrm{HT}_{4}$ rats; ${ }^{\mathrm{c}}$ significant vs. $\mathrm{HT}_{3}$ rats. The level of significance was chosen as $P<0.05$.

Fig. 5. Electrophoretic analysis of liver mitochondria. from hypothyroid $(\mathrm{H})$, hypothyroid $\mathrm{T}_{4}$-treated $\left(\mathrm{HT}_{4}\right)$, hypothyroid $\mathrm{T}_{3}$-treated $\left(\mathrm{HT}_{3}\right)$, and hypothyroid $\mathrm{T}_{3}$-treated and cold-exposed $\left(\mathrm{HT}_{3}+\mathrm{CE}\right)$ rats. The mitochondrial preparations (1 $\mathrm{mg}$ protein/ml) were solubilized with (2\%) sodium dodecyl sulfate and (10\%) mercaptoethanol, subjected to electrophoresis in $12 \%$ polyacrylamide gels, and stained with Coomassie blue as described in 
Materials and Methods. Molecular weight markers are shown on the left of protein stain panel. The blots shown are representative of five independent analyses for each group.

Fig. 6. Levels of PGC-1, NRF-1, and NRF-2 mRNA expression in liver from hypothyroid (H), hypothyroid T ${ }_{4}^{-}$ treated $\left(\mathrm{HT}_{4}\right)$, hypothyroid $\mathrm{T}_{3}$-treated $\left(\mathrm{HT}_{3}\right)$, and hypothyroid $\mathrm{T}_{3}$-treated and cold-exposed $\left(\mathrm{HT}_{3}+\mathrm{CE}\right)$ rats, were analysed by quantitative Real Time PCR.

Values reported in graphs are means \pm SEM of four independent Real Time PCR experiments and are normalized to the $\beta$-actin expression levels.

Fig. 7. Levels of PGC-1, NRF-1, and NRF-2 protein expression in rat liver. Liver total proteins from hypothyroid $(\mathrm{H})$, hypothyroid $\mathrm{T}_{4}$-treated $\left(\mathrm{HT}_{4}\right)$, hypothyroid $\mathrm{T}_{3}$-treated $\left(\mathrm{HT}_{3}\right)$, and hypothyroid $\mathrm{T}_{3}$-treated and cold-exposed $\left(\mathrm{HT}_{3}+\mathrm{CE}\right)$ rats, were isolated and analysed using Western blot analyses. A representative result of 3 independent experiments is shown. Values reported in graphs are means \pm SEM of three independent experiments. Ratios of band intensities to the $\beta$-actin band intensities were compared with a standard hypothyroid sample that was assigned a value of 1.

Fig. 8. Relationship between protein expression and COX activity in liver from hypothyroid (H), hypothyroid $\mathrm{T}_{4}$-treated $\left(\mathrm{HT}_{4}\right)$, hypothyroid $\mathrm{T}_{3}$-treated $\left(\mathrm{HT}_{3}\right)$, and hypothyroid $\mathrm{T}_{3}$-treated and cold-exposed $\left(\mathrm{HT}_{3}+\mathrm{CE}\right)$ rats. Values of $\mathrm{COX}$ activity in treatment groups were expressed relative to values found in hypothyroid group. 
$\square_{\mathrm{H}} \bigotimes_{\mathrm{HT}_{4}} V_{\mathrm{HT}_{3}} \mathrm{HT}_{3}+\mathrm{CE}$

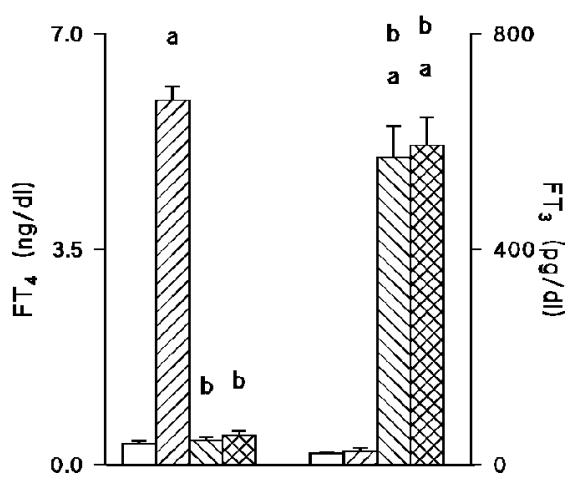

Fig. 1 


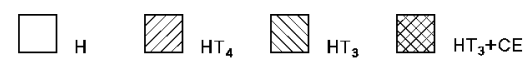
HOMOGENATE



MITOCHONDRIA

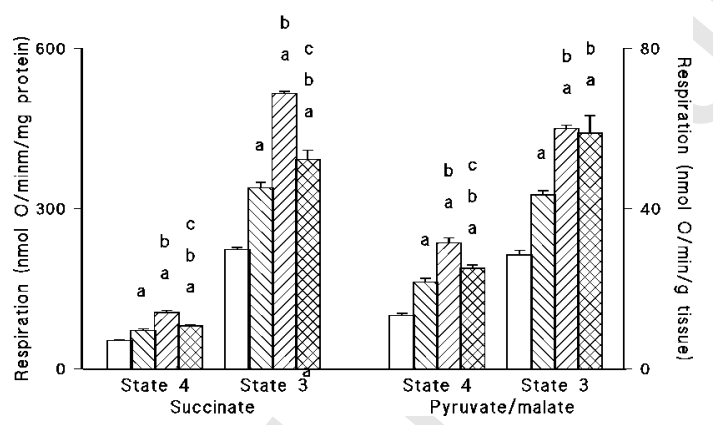

Fig. 2 


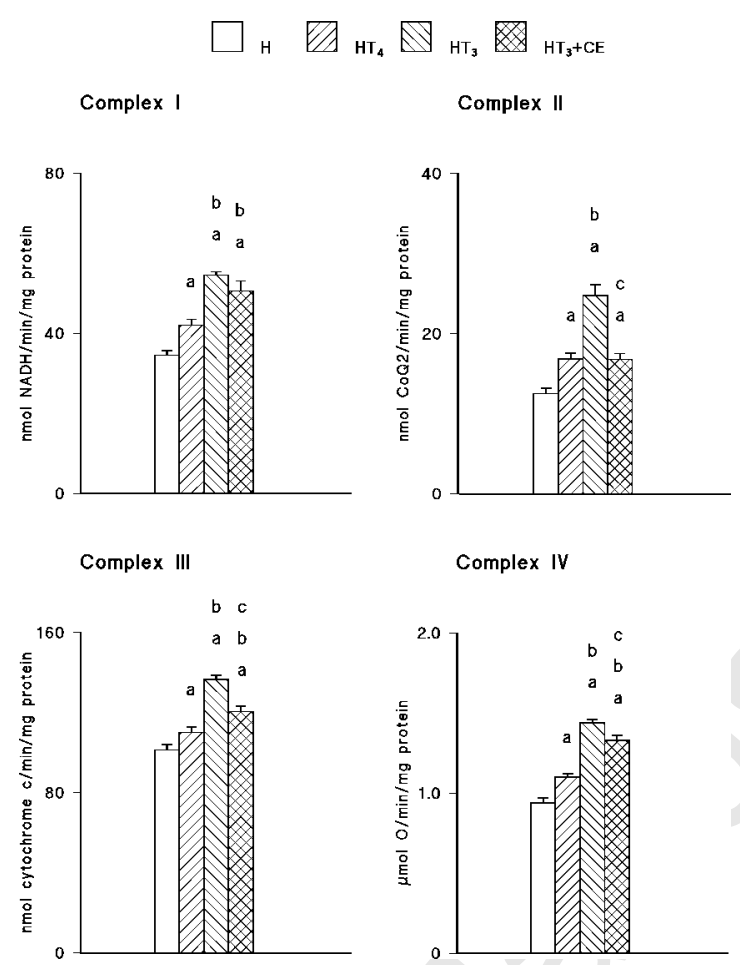

Fig. 3 
$\square_{\mathrm{H}} \Downarrow_{\mathrm{HT}_{4}} \quad \mathrm{HT}_{\mathrm{HT}_{3}}{ }_{\mathrm{HT}_{3}+\mathrm{CE}}$
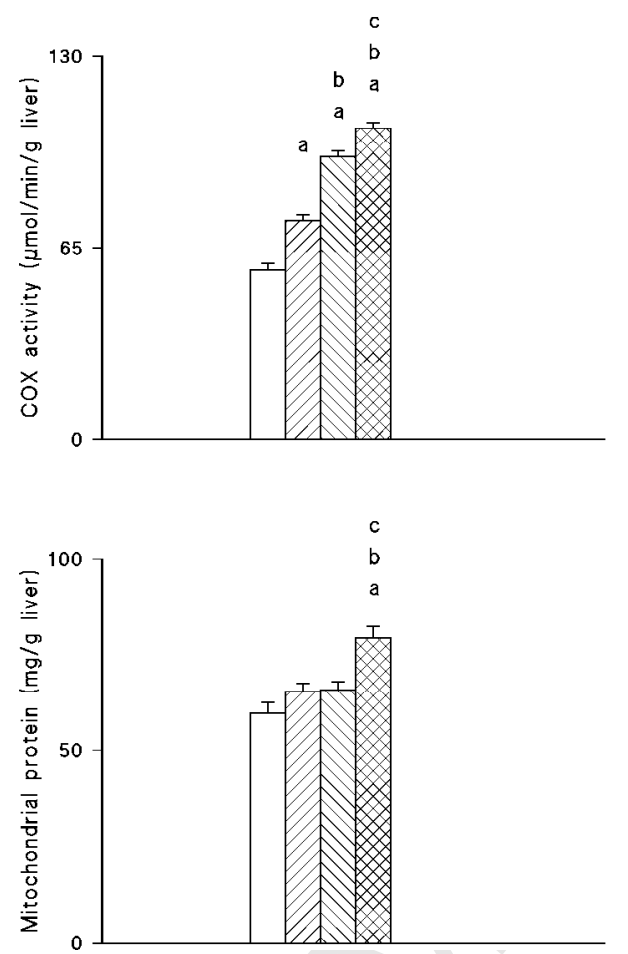

Fig. 4 


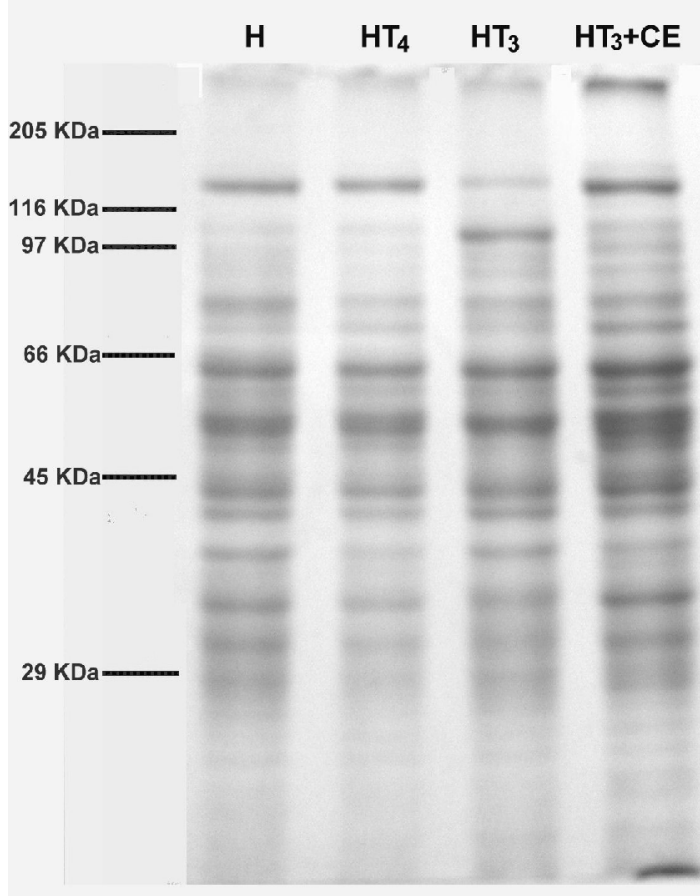

Fig. 5 
$\square \mathrm{H} \square \mathrm{HT}_{4} \quad \mathrm{HT}_{3} \otimes \mathrm{HT}_{3}+\mathrm{CE}$
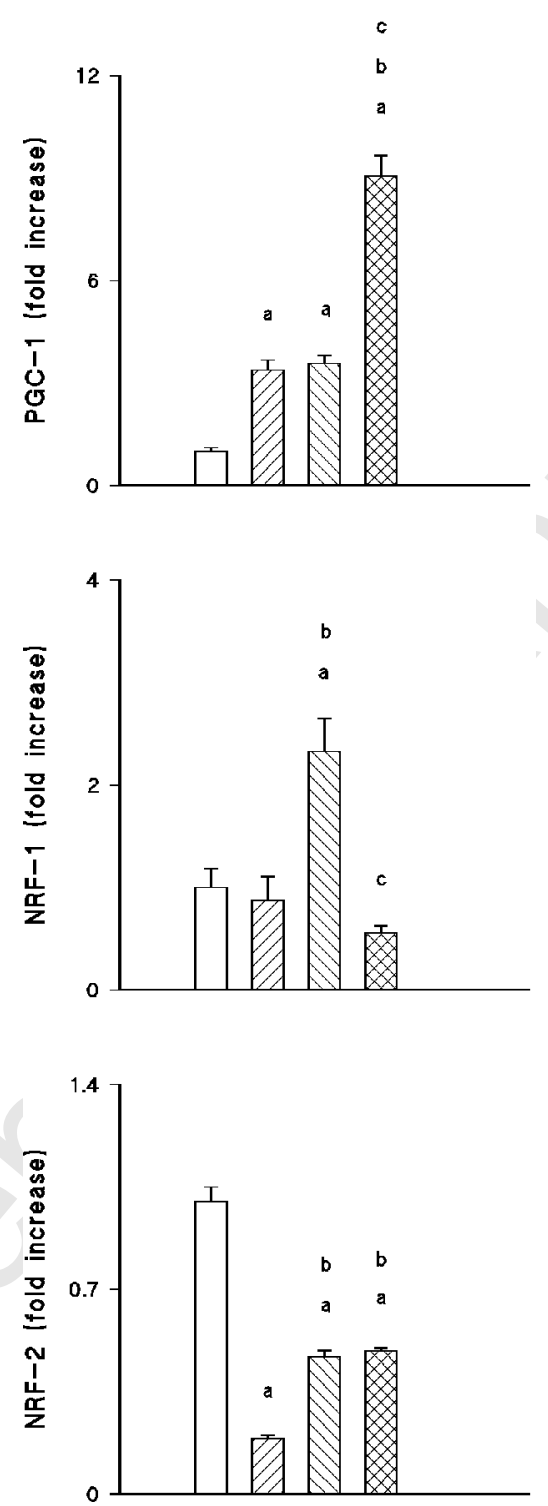

Fig. 6 


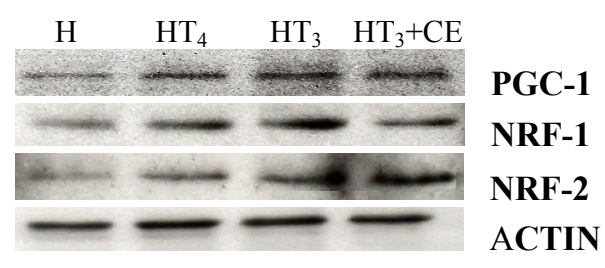

$\square{ }_{\mathrm{H}} \square \mathrm{HT}_{4} \mathrm{HT}_{3} \mathrm{HT}_{3}+\mathrm{CE}$
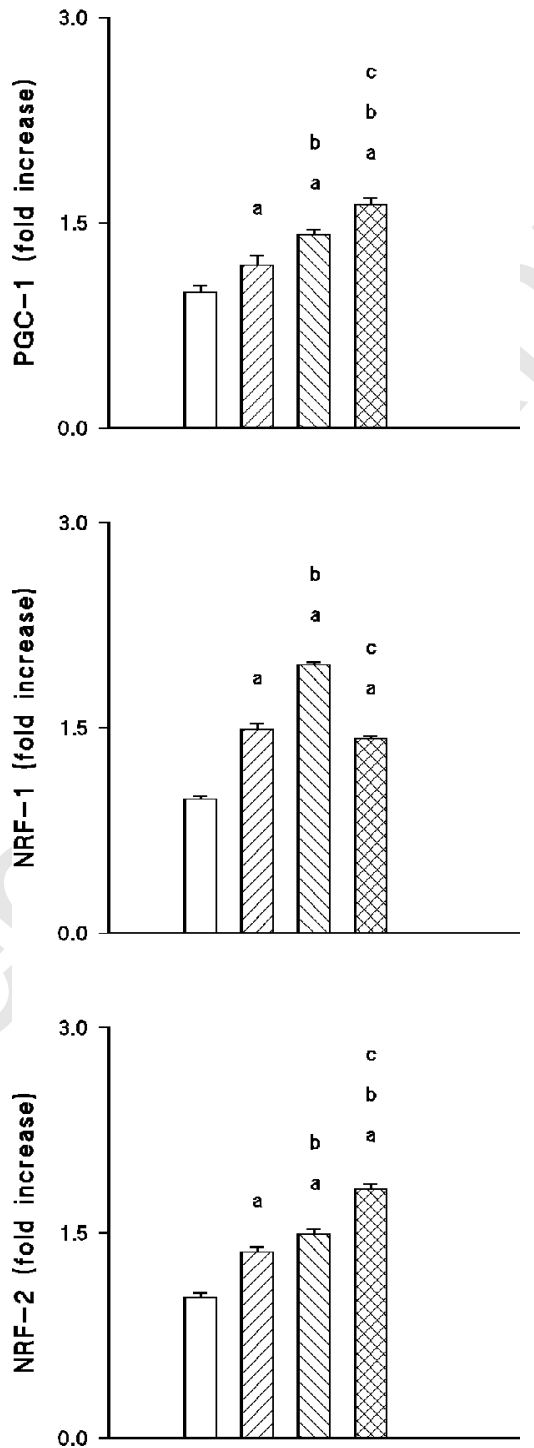

Fig. 7 

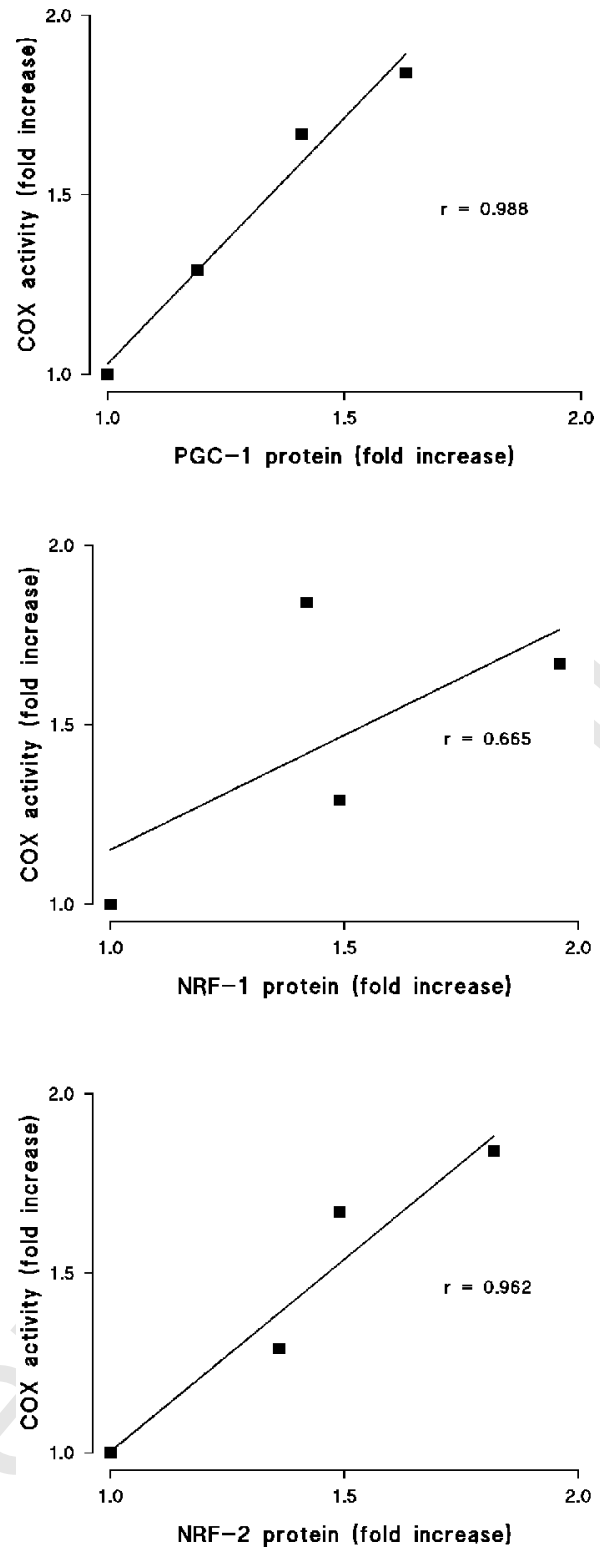

Fig. 8 